\title{
PERAN WARGA SEKOLAH DALAM PEMBUDAYAAN NILAI-NILAI EDUKATIF LAGU-LAGU MINANG MELALUI GERAKAN LITERASI DI SEKOLAH DASAR
}

\author{
Desyandri \\ Jurusan Pendidikan Guru Sekolah Dasar, Fakultas Ilmu Pendidikan \\ Universitas Negeri Padang \\ desyandri@fip.unp.ac.id
}

\begin{abstract}
ABSTRAK
Artikel ini bertujuan untuk mengungkap dan menginterpretasikan peran warga sekolah dalam menumbuhkembangkan literasi budaya melalui lagulagu Minang di sekolah dasar. Peran tersebut ditentukan oleh latar belakang, peran, dan intervensi budaya serta menjalin hubungan kerjasama yang baik antar warga sekolah, memberikan contoh sikap tauladan, sehingga memunculkan kesadaran kolektif untuk senantiasa membudayakan nilai-nilai edukatif tersebut dalam kehidupan sehari-hari peserta didik secara kontiniu, baik ketika berada di sekolah atau dimasyarakat.
\end{abstract}

Kata kunci: Pembudayaan, Nilai-Nilai, Edukatif, Lagu Minang, Literasi

\section{PENDAHULUAN}

Adat Minangkabau sebagai bagian dari khazanah budaya memiliki keunikan tersendiri dan merupakan aset Provinsi Sumatera Barat. Adat Minangkabau bermanfaat bagi bangsa dan negara terutama bagi etnis Minang sendiri menuju masyarakat yang maju, beradat,berbudaya tinggi, dan berkarakter dalam mengisi pembangunan bangsa dalam wadah Negara Kesatuan Republik Indonesia (NKRI).

Adat Minangkabau dirancang berdasarkan akal-budi (perpaduan antara pikiran dan perasaan untuk menimbang baik dan buruk mengacu pada alam takambang jadi guru, raso jo pareso (rasa/karsa dengan periksa/kontrol) yang menurut alua jo patuik (alur dan patut) akan melahirkan tindakan (sikap dan perilaku) yang baik dengan mempertimbangkan perasaan malu dan sopan, agar memunculkan kearifan pengetahuan dan berperilaku sebagai manusia dalam kehidupan sosial yang beradab (Zainuddin, 2010:106). Adat Minangkabau memberikan acuan atau pedoman nilai-nilai yang bersumberkan dari akal-budi dalam menjalani kehidupan, sehingga melahirkan tindakan dan perilaku masyarakat yang mencerminkan karakter khas orang Minangkabau. 
Adat Minangkabau berisikan hal-hal mendasar, seperti: falsafah Adat Basandi Syarak - Syarak Basandi Kitabullah (ABS-SBK) dan Alam Takambang Jadi Guru. Inti sari nilai-nilai dasar ABS-SBK tersebut menjelaskan bahwa adat Minangkabau bersendikan syari'at dan syari'at bersendikan kitabullah (Alquran). Adat Minangkabau menyandarkan diri pada ajaran agama Allah yakni Islam yang memegang teguh Alquran dan Hadis Rasulullah. Nilai-nilai dasar tersebut dijadikan sebagai pedoman dasar untuk mewujudkan masyarakat Minangkabau yang aman dan makmur secara lahir dan batin, berbudi luhur, berakhlak mulia, dan diridai Allah SWT, sedangkan Alam Takambang Jadi Guru, menurut Idrus Hakimy (1987:2) bahwa alam yang terkembang sebagai ciptaan Allah dapat dipelajari dengan seksama dan merupakan sumber pengetahuan, pada ahirnya dapat mengarahkan dan memberikan pedoman bagi masyarakat dalam melahirkan tindakan atau perilaku yang beradat, beradab, dan berkarakter.

Falsafah di atas membuktikan bahwa secara ideal adat Minangkabau telah memberikan bekal nilai-nilai bagi orang Minang dalam mengarungi kehidupan seharihari, baik kehidupan individu maupun kehidupan bermasyarakat. Nilai-nilai tersebut dijadikan sebagai sarana edukatif bagi orang Minang untuk mewujudkantujuan adat Minangkabau, yakni membentuk orang Minang yang berbudi luhur, berbudaya, dan beradab.

Pembudayaan nilai-nilai adat Minangkabau telah dilakukan secara turun-temurun dengan berbagai cara. Dalam masyarakat Minangkabau, salah satu cara yang digunakan adalah melalui seni pertunjukan atau kesenian Minang, seperti yang dikemukakan Amir (2011: 76) bahwa "adat-istiadat merupakan aneka kelaziman dalam suatu nagari. Kelaziman ini pada umumnya menyangkut pengejawantahan unjuk rasa seni budaya masyarakat, seperti acara-acara keramaian anak nagari (generasi muda), seperti pertunjukan randai, saluang, aneka tari-tarian, dan aneka ragam kesenian. Amir menambahkan, bahwa kebanyakan adat atau nilai-nilai sopan-santun, basa-basi, serta tata krama pergaulan termasuk dalam klasifikasi "adat-istiadat".

Salah satu diantara jenis kesenian yang ada di Minangkabau adalah lagu-lagu Minang atau dikenal juga dengan sebutan lagu-lagu Minang lamo (lama). Lagu-lagu Minang merupakan ungkapan perasaan dan pemikiran seniman Minang yang dituangkan ke dalam bentuk musik dan lagu yang mengandung nilai-nilai dan menggambarkan kondisi realitas yang terjadi di masyarakat, serta proses aktualisasi nilai-nilai yang terkandung dalam adat Minangkabau. Nilai-nilai tersebut dijadikan sebagai pedoman 
dalam melahirkan tindakan dan perilaku yang mencerminkan karakter orang Minang. Barendregt (2002: 416) mengatakan bahwa:

Minang songs, provides one of the avenues through which identification as Minangkabau is experienced, defined, and consumed internally. It constructs a Minangkabau sensibility "by depicting a recognizable landscape through the use of metaphors" related to migration and the homeland.

Lagu-lagu Minang dapat mengidentifikasikanadat budaya Minangkabau yang dianut, didefinisikan, dan dikonsumsi secara internal serta dapat membangun serta menggambarkan perasaan tentang keindahan alam yang dapat dikenali melalui penggunaan metafora terkait dengan ranah Minang dan kebiasaan atau tradisi merantau."The attachment goes beyond this landscape to "a community sharing the same moral values" (ibid.:417). Lagu-lagu Minang lebih dari sekedar menceritakan tentang kerinduan terhadap alam Minangkabau, bahkan merupakan upaya masyarakat untuk berbagi nilai-nilai moral.

Hal tersebut senada dengan pendapat Hajizar (2012) yang menyatakan bahwa lagu-lagu Minang berangkat dari resepsi nilai-nilai sosial masyarakat. Dengan demikian, lagu-lagu Minang dapat digambarkan sebagai sebuah keintiman atau kedekatan dengan budaya Minangkabau,seperti yang dikemukakan Fraser (2011), “Minang songs is a form of cultural intimacy, one that allows the Minangkabau to recognize themselves within the nation as distinct from its other constituents".

Lagu-lagu Minang memiliki dua unsur pokok, yakni unsur musik dan lirik. Pertama, unsur musik lagu-lagu Minang memiliki kekhasan Minangkabau. Lagu-lagu Minang memiliki beragam alat musik yang khas Minang, seperti talempong, gandang, bansi, saluang, rabab, dan kecapi. Sebagai sebuah genre pop, musik Minang mengalami akulturasi dengan musik modern, sehingga peralatan musiknya merupakan perpaduan dengan alat musik modern, seperti keyboard, electric guitar, saxophone, terompet. Irama dan melodi lagu-lagu Minang memiliki nuansa unik, yakni memiliki cengkok (gariniak) Minang, seperti yang diungkapkan Budiman (2011) bahwa lagu-lagu Minang disampaikan dalam alunan melodi yang kental dengan keunikan "gariniak" atau cengkok Minang.

Kedua, unsur lirik lagu-lagu Minang memiliki lirik yang berbentuk sajak dan pantun, seperti yang diungkapkan Darwis (2005) bahwa pantun pernah memegang peranan penting dalam kesenian Minangkabau. Orang Minang sering mengungkapkan perasaannya dengan pantun, berdialog, bahkan bersahutan kata. Dahulu pantun sangat 
dimengerti dan dihayati oleh orang Minang, termasuk anak muda, orang dewasa sampai pada orang tua, baik pria maupun wanita.

Kekuatan lagu-lagu Minang terletak pada nilai-nilai yang terkandung dalam lirik lagu yang mencerminkan nilai-nilai adat Minangkabau. Budiman (2011) mengemukakan bahwa lirik memberikan indikasi bahwa "Pusako urang Minang tu, iyolah kato" artinya pusaka orang Minang itu adalah kata. "Kato bakieh (kata sindiran), kato bamukasuik (kata yang ditujukan untuk...), tanyo baalamat (pertanyaan yang jelas), manggado manghadang tampuak (hal-hal yang tepat sasaran), balaia manghadang pulau (upaya untuk menyelesaikan petualangan)". Setiap kata memiliki maksud dan tujuan tertentu. Di samping itu, lirik lau-lagu Minang memiliki nilai-nilai kearifan yang santun dan menuntun. Hal ini juga ditemukan oleh Desyandri (2015) bahwa dari dua lagu Minang (lagu Minangkabau dan Kampuang nan Jauah di Mato) terkandung 9 nilai-nilai edukatif, yaitu ketuhanan (syara' atau agamo), kecintaan terhadap ranah minang, persaudaraan dan gotong royong, kesatuan dan kebersamaan, musyawarah dan mufakat, adil dan damai, keteguhan hati, waspada, dan disiplin.

Selain kekhasan musik dan nilai-nilai yang terkandung dalam lirik lagu-lagu, lagu-lagu Minang terbukti sangat dekat dengan pendengar atau masyarakat pendukungnya. Hal ini terlihat dari kepopuleran lagu-lagu Minang yang tidak hanya di wilayah Minangkabau, akan tetapi beberapa lagu tersebut telah dikenal secara nasional hingga ke manca negara dan bahkan dapat dikatakan bahwa beberapa lagu Minang tergolong lagu-lagu yang melegenda. Kepopuleran dan kedekatan lagu-lagu Minang dengan masyarakat pendukung menandakan bahwa pesan nilai-nilai yang terkandung dalam lagu-lagu Minang diterima dan hidup di hati masyarakat Minangkabau. Musik dan lirik lagu-lagu Minang mengedukasi pendengar atau pendukungnya untuk selalu mengikuti nilai-nilai adat Minangkabau dan memperlihatkan perilaku yang berbudi luhur, bertutur kata yang sopan dan santun, cinta kampung halaman, dan memberikan kesadaran untuk selalu menjunjung tinggi budaya sendiri.

Kondisi ini berbanding terbalik dengan realitas yang ada sekarang ini. Melihat kondisi ideal pendidikan sebagai upaya normatif dalam perberdayaan dan pembudayaan khususnya di wilayah Minangkabau atau Sumatera Barat pada kondisi sekarang, secara umum masih menyisakan berbagai permasalahan, seperti tercerabutnya orang Minang dari budayanya sendiri, seperti yang dikemukakan Naim (2003) bahwa permasalahan besar yang dihadapi masyarakat Minangkabau adalah hilangnya hal yang paling berharga dari diri mereka, yaitu jati diri. Jati diri yang dimaksudkan adalah nilai-nilai adat 
Minangkabau yang menjadi ajaran dan tujuan adat Minangkabau. Permasalahan ini menggambarkan bahwa pendidikan sebagai proses pembudayaan dalam upaya menanamkan nilai-nilai positif adat Minangkabau dan nilai-nilai edukatif lagu-lagu Minang khususnya di wilayah Minangkabau atau Sumatera Barat selama ini belum terlaksana dengan optimal.

Permasalahan tersebut diperparah lagi dengan bergulirnya arus globalisasi. Globalisasi yang terjadi pada abad kedua puluh satu yang ditandai dengan pesatnya perkembangan ilmu pengetahuan, teknologi, dan seni (IPTEKS), di satu pihak dapat memberikan keuntungan dan kemudahan bagi pendidikan dan masyarakat Minangkabau dalam memperoleh informasi dan ilmu pengetahuan tanpa batas,di lain pihak mengancam dan membahayakaneksistensi adat Minangkabau dan lagu-lagu Minang.

Dampak globalisasi secara langsung atau tidak langsung telah membawa wajah baru dalam penampilan adat budaya (Sairin, 2004). Masyarakat Minangkabau yang semakin kuat berinteraksi dengan masyarakat dunia pada saat sekarang tidak terhindarkan menyerap berbagai nilai budaya dari ranah budaya universal (Amir, 2007). Masyarakat Minangkabau mengalami kegoncangan budaya yang menyeret generasi muda untuk mencari jalan hidupnya sendiri-sendiri dengan kontrol budaya yang lemah (Sairin, 2004).

Realitas yang terjadi di lapangan menunjukkan bahwa secara kuantitas seiring dengan perkembangan zaman memperlihatkan kondisi perilaku peserta didik dan masyarakat yang semakin mengkhawatirkan, seperti berita yang dirilis Harian Padang Ekspres 29 April 2013 bahwa satu per satu peserta didik di Kota padang tersandung kasus hukum, baik yang disebabkan tawuran antar pelajar, pencurian, maupun kasus kepemilikian narkoba. Selain itu, Riadi (2014) dilansir Republika memberitakan bahwa hari kelulusan diwarnai dengan tawuran pelajar di Ruang Terbuka Hijau (RTH) Imam Bonjol Kota Padang. Fakta ini menggambarkan bahwa proses pendidikan belum berjalan dengan optimal dan menjauh dari nilai-nilai adat Minangkabau.

Dua mata pelajaran di sekolah dasar yang berkaitan langsung dengan proses pelestarian dan pembudayaan nilai-nilai adat Minangkabau dan lagu-lagu Minang, yakni Budaya Alam Minangkabau (BAM) dan Pendidikan Seni Musik masih belum optimal. Pertama, pelajaran BAM yang dilakukan masih sebatas mengenalkan pepatah dan petatah-petitih adat Minangkabau. Belum dilanjutkan dengan pemahaman dan pengaktualan nilai-nilai tersebut dalam melahirkan perilaku peserta didik yang mencerminkan watak orang Minang. Sayuti (2012) Ketua Lembaga Kerapatan Adat Alam Minangkabau (LKAAM) Provinsi Sumatera Barat yang dilansir Antara Sumbar, menilai 
pelajaran BAM sebagai bagian dari Muatan Lokal di sekolah belum efektif, hal ini disebabkan oleh empat faktor, yakni: (1) minimnya dukungan dana, (2) terbatasnya guru, (3) terbatasnya bahan kurikulum, dan (4) terbatasnya bahan ajar. Kondisi kurang maksimalnya pelaksanaan pembelajaran BAM di sekolah menjadikan semakin pupusnya upaya pelestarian nilai-nilai adat Minangkabau, pada akhirnya menyebabkan tercerabutnya peserta didik dari budaya sendiri.

Kedua, realita pendidikan dan pembelajaran pendidikan seni musik di sekolah, khususnya di Kota Padang juga ditengarai belum optimal. Berikut dipaparkan hasil pengamatan dan pengalaman peneliti yang dikombinasikan dengan hasil studi pendahuluan (Februari hingga Juni 2013) bahwa proses pembelajaranbelum optimal dan lebih berorientasi pada penguasaan kemampuan intelektual semata, mengabaikan prosespelestarian dan aktualisasi nilai-nilai adat Minangkabau dan nilai-nilai edukatif yang terkandung dalam lagu-lagu Minang, sehingga pendidikan hanya dijadikan sebagai alat untuk memperkaya pengetahuantetapi miskin nilai-nilai. Tilaar (2010:218) mengemukakan bahwa intelektualisme yang telah menjadi ciri pendidikan nasional telah mengasingkan budaya dan apresiasi budaya dalam pendidikan nasional. Bukan berarti bahwa kognisi tidak diperlukan dalam pengembangan kepribadian manusia.

Pandangan Tilaar terlihat dalam realita pembelajaran pendidikan seni musik di sekolah-sekolah. Pembelajaran didominasi fungsi hiburan semata, pemberian materi dalam bentuk hafalan musik/lagu-lagu Minang, mengekplorasi kandungan nilai-nilai edukatifsecara garis besar tanpa dilanjutkan dengan pengimplementasian dan pembudayaan nilai-nilai tersebut dalam kehidupan sehari-hari peserta didik. Bahkan sekolah-sekolah di Kota Padang terlihat mulai meninggalkan lagu-lagu Minang, sehingga nilai-nilai edukatif yang terkandung dalam lagu-lagu tersebut tidak lagi difungsikan sebagaimana mestinya. Hal ini dapat dibuktikan dengan sedikitnya lagu-lagu Minang yang dibelajarkan di sekolah dan kebanyakan peserta didik kurang mengetahui lagu-lagu Minang. Seharusnya pendidikan seni musik dapat mengembangkan rasa keindahan, kreativitas, dan kepribadian, serta menjadikan peserta didik lebih produktif dan berbudaya (Astuti: 2010: 5).

Permasalahan ini dapat menyebabkan munculnya kecenderungan perilaku dan karakter peserta didik yang tidak beradat/tidak beradab, seperti: kurangnya rasa menghargai dan menghormati orang lain, kurangnya sopan-santun, lebih mementingkan diri sendiri, serta kurang peduli dengan adat atau budaya daerah mereka sendiri. Perilaku negatif ini, jika dibiarkan terus-menerus mengakibatkan tercerabutnya peserta didik dari 
budayanya sendiri.Orang Minang yang tidak tahu dengan adat Minangkabau. Seperti kata pepatah Minang, "Lah lupo kacang jo kuliknyo", maksud pepatah ini menggambarkan seseorang yang telah lupa dengan adat budayanya sendiri.

Berdasarkan permasalahan yang diungkap sebelumnya dan untuk menghindari ketercerabutan budaya, diperlukan upaya pelestarian dan pembudayaan nilai-nilai edukatif lagu-lagu Minang. Salah satu upaya yang dapat dilakukan dalam melestarikan dan membudayakan kembali nilai-nilai edukatif tersebut dengan menumbuhkembangkan gerakan literasi budaya melalui lagu-lagu Minang.

\section{PEMBAHASAN}

Literasi budaya melebihi kemampuan "baca-tulis". Litrerasi budaya dapat didefinisikan sebagai jaringan informasi yang dimiliki oleh pembaca kompeten, sebagai dasar informasi yang melekat di pikiran dan dipahami, memperoleh intinya, memahami implikasinya, menghubungkan apa yang mereka baca dengan konteks yang tidak tertulis yang memberi makna terhadap bacaan. Hirsc dalam Hoffman (1991: 2) mengemukakan bahwa:

What is cultural literacy? Cultural literacy is infinitely more than the ability to accomplish the tasks of reading and writing. Hirsch defines cultural literacy as "the network of information that competent readers possess. ... It is the background information, stored in their minds, that enables them to take up a newspaper and read it with an adequate level of comprehension, getting the point, grasping the implications, relating what they read to the unstated context which alone gives meaning to what they read".

Menurut World Economic Forum 2015 dalam Kemendikbud (2016) mengemukakan bahwa literasi adalah kemampuan memahami teks, angka, dan simbol tertulis baik cetak maupun digital dalam berbagai bidang dan menggunakannya untuk meningkatkan kualitas hidup baik personal maupun sosial dan literasi budaya adalah kemampuan memahami kebudayaan sebagai identitas bangsa dan warga negara sebagai unsur masyarakat yang mampu melaksanakan hak dan kewajiban untuk meningkatkan kualitas hidupnya dan orang lain.

Peran pendidikan dan sekolah sangat dominan dalam menumbuhkembangkan gerakan literasi budaya. Pendidikan dan kebudayaan merupakan dua hal yang tidak dapat dipisahkan dan saling terkait satu sama lain. Dengan arti kata, bahwa pendidikan tidak terlepas dari kebudayaan dan begitupun kebudayaan tidak terlepas dari pendidikan. Pandangan ini memerlukan tindak lanjut untuk mensinergikan pendidikan dan 
kebudayaan. Pendidikan memiliki peranan penting untuk menanamkan nilai-nilai kebudayaan, diantaranyanilai-nilai adat Minangkabau dan lagu-lagu Minang.

Ki Hadjar Dewantara (Ki Suratman, 1987:12) mengatakan bahwa pendidikan ialah usaha kebudayaan yang bermaksud memberi bimbingan dalam hidup tumbuhnya jiwa raga peserta didik, agar dalam kodrat pribadi dan pengaruh lingkungandapat memperoleh kemajuan lahir batin menuju ke arah adab kemanusiaan. Kepribadian seseorang terbentuk karena nilai-nilai budaya yang terdapat di lingkungan seseorang itu dilahirkan, dibesarkan, dan dididik. Tanpa kebudayaan tidak mungkin lahir suatu kepribadian. Oleh sebab itu, proses pendidikan tidak bisa lain adalah proses pembudayaan.

Pendidikan sebagai proses pembudayaan bukan hanya merupakan proses transformasi pengetahuan yang terfokus pada penguasaan kemampuan intelektual semata, tetapi juga berperan mewariskan nilai-nilai positif budaya dan kearifan lokal sebagai tuntunan dalam melahirkan tindakan dan perilaku. Dengan kata lain, pendidikan seharusnya berupaya menjadikan nilai-nilai edukatif adat Minangkabau dan lagu-lagu Minang sebagai pedoman untuk melahirkan tindakan dan perilaku peserta didik. Upaya pembudayaan tersebut dapat dijadikan sebagai sarana untuk menumbuhkan dan membangun karakter peserta didik.

Muhadjir (2003:20) mengemukakan tiga fungsi pendidikan, yaitu: (1) menumbuhkan kreativitas peserta didik; (2) memperkaya khasanah budaya manusia, memperkaya isi nilai-nilai insani dan nilai-nilai Ilahi; dan (3) menyiapkan tenaga kerja produktif. Pandangan-pandangan tentang pendidikan yang telah dikemukakan tersebut dapat diambil sebuah benang merah bahwa pendidikan merupakan upaya pemberdayaan dengan menumbuhkan kreativitas peserta didik agar menjadi manusia yang kaya dengan nilai-nilai insani dan Ilahi, serta berbudaya.

Ditinjau dari tujuan pendidikan, Tilaar (2010:20-21) mengemukakan bahwa tujuan pendidikan bukan hanya manusia yang terpelajar tetapi manusia yang berbudaya, sehingga pendidikan dapat berfungsi sebagai proses pemberdayaan dan proses pembudayaan.Pendidikan sebagai proses pemberdayaan dan pembudayaan mengisyaratkan bahwa pendidikan memiliki tugas menumbuhkembangkan nilai-nilai positif yang terkandung dalam sebuah kebudayaan. Di pihak lain, Muhadjir (2003:97) mengemukakan pendidikan adalah upaya normatif untuk mencapai sesuatu tujuan. Tujuan pendidikan adalah terjadinya tingkat perkembangan normatif yang lebih baik pada peserta didik. Dengan kata lain, pendidikan dimaksudkan untuk menumbuhkembangkan 
sikap dalam rangka membangun karakter peserta didik yang membawa pewarisan nilainilai positif serta pembentukan sikap dan kesadaran untuk masa depan budaya yang lebih baik.

\section{Lagu-lagu Minang sebagai Sarana Edukatif}

Menyikapi kandungan nilai-nilai yang terkandung dalam lagu-lagu Minang yang memiliki pesan atau nasehat dan bersifat menuntun individu dan masyarakat Minangkabau agar melahirkan pola pikir, tindakan, dan perilaku yang sesuai dengan norma dan etika adat Minangkabau merupakan nilai-nilai yang bersifat mendidik (memberikan didikan), sehingga nilai-nilai yang terkandung dalam lagu-lagu Minang dapat dikatakan sebagai nilai-nilai edukatif yang dapat dimanfaatkan untuk membangun karakter dan menciptakan kehidupan yang aman, tenteran, adil, dan damai.

Nilai-nilai yang bersifat menuntun atau mendidik (nilai-nilai edukatif) individu dan masyarakat agar memiliki pola pikir, tindakan, dan perilaku yang sesuai dengan norma atau aturan adat budaya Minangkabau sangat cocok dan dibutuhkan di sekolahsekolah, khususnya di lingkungan pendidikan dasar. Nilai-nilai tersebut bermanfaat sebagai tonggak dalam mempersiapkan generasi penerus Minangkabau yang beradab, beradat, dan berkarakter mulia.

Lagu-lagu Minang dan nilai-nilai yang terkandung di dalamnya dijadikan sebagai salah satu sumber ilmu pengetahuan dalam berbagai mata pelajaran di lingkungan pendidikan dasar, khususnya mata pelajaran seni budaya (seni musik) dan Budaya Alam Minangkabau (BAM). Salah seorang guru (WL) mengemukakan pandangannnya terhadap lagu-lagu Minang, seperti petikan wawancara pada tanggal 30 Desember 2014 di bawah ini:

Awalnyo siswa ndak mengerti, kan? Karena lagu Minang tu, nyo kaya, istilahnyo ada simbol-simbol, kemudian pesan yang disampaikan. Nah, lagu Minang berkaitan dengan budaya Minangkabau, jadi disuruah mereka memahami lagu tu dulu, sampai mereka memaknai. Lagu-lagu Minang merupakan sarana ampuh untuak mambantuak karakter siswa.

Pada awalnya peserta didik belum sepenuhnya memahami tentang lagu-lagu Minang, apalagi kecenderungan generasi muda Minangkabau sekarang kurang memperhatikan adat budaya mereka sendiri dan lebih cenderung mengikuti perkembangan adat budaya nasional bahkan global. Lagu-lagu Minang sangat kaya dengan bahasa-bahasa khas yang jarang digunakan pada zaman sekarang dan memiliki makna konotasi yang tinggi, sehingga perlu upaya lanjut untuk mempelajari bahasa 
tersebut. Untuk mengetahui dan melaksanakan anjuran atau nasehat yang ada pada lagu, perlu diberikan pemahaman kepada peserta didik sampai mereka memaknai lagu tersebut.

Pandangan lain tentang lagu-lagu Minang dikemukakan oleh guru-guru pada tingkat pendidikan dasar (SD dan SMP) kota Padang yang menyatakan bahwa secara umum mereka mengetahui tentang lagu-lagu Minang dan sangat menyenangi atau menyukai lagu-lagu tersebut, khususnya lagu-lagu Minang lama (klasik). Apalagi lagulagu Minang lama tersebut sering dibelajarkan dan didengar di sekolah-sekolah. Guru seni musik mengemukakan pandangannya terhadap lagu-lagu Minang yang dibelajarkan di sekolah, seperti petikan wawancara pada tanggal 4 Februari 2015, "Uni suko lagu-lagu Minang lamo, o... kek lagu-lagu Efrinon, Elly Kasim, tapi kalau Minang-minang yang kini kurang nyeh. Soal nyo, nilai-nilai pendidikannyo kurang".

Lagu-lagu Minang lama yang digunakan dalam pendidikan, terutama di lingkungan pendidikan dasar (SD dan SMP) kota Padang, provinsi Sumatera Barat secara garis besar merupakan lagu-lagu Minang lama yang berkualitas tinggi, memiliki kandungan pesan-pesan atau nilai-nilai yang menuntun atau memberikan nasehat agar pemikiran, tindakan, dan perilaku peserta didik sesuai dengan norma atau adat Minangkabau, atau dengan kata lain nilai-nilai yang terkandung dalam lagu-lagu Minang dapat dijadikan sebagai sarana ampuh dalam membangun karakter peserta didik.

Mengacu pada pandangan yang dikemukakan oleh guru-guru terhadap jumlah lagu-lagu Minang yang dibelajarkan di sekolah-sekolah pada tingkat pendidikan dasar kota Padang sebelumnya dibandingkan dengan lagu-lagu Minang lama lainnya yang juga memiliki kandungan nilai-nilai edukatif dan terkenal serta dekat di hati masyarakat, masih terlalu sedikit dan belum mengakomodasi secara keseluruhan nilai-nilai yang dibutuhkan dan diharapkan dalam upaya membangun karakter peserta didik. Pandangan yang dikemukakan guru-guru sebelumnya terlihat bahwa nilai-nilai yang terkandung pada lagu-lagu Minang baru sebatas dibaca dan diketahui. Untuk itu, perlu upaya lebih lanjut agar nilai-nilai tersebut dipahami dan diimplementasikan dalam kehidupan sekolah maupun masyarakat mengisyaratkan perlunya upaya untuk mengimplementasikan gerakan literasi budaya.

Peran dalam rangka menumbuhkembangkan literasi budaya melalui seni musik yang dilakukan oleh warga sekolah di sekolah dasar mengacu pada upaya belajar budaya yang dikemukakan oleh Kuntjaraningrat (2011: 142-147) bahwa proses belajar kebudayaan sendiri meliputi proses internalisasi, sosialisasi, dan enkulturasi. 


\section{Proses Internalisasi}

Proses internalisasi merupakan suatu aktivitas berkelanjutan yang dilakukan oleh kepala sekolah, guru-guru, dan orang tua/masyarakat dalam mengenalkan dan menanamkan nilai-nilai edukatif lagu-lagu Minang dalam membangun kepribadian peserta didik yang berkarakter.

\section{Kepala sekolah}

Proses internalisasi nilai-nilai edukatif lagu-lagu Minang untuk membangun karakter peserta didik yang dilakukan kepala sekolah dapat dikemukakan sebagai berikut:

a) Menumbuhkan kesadaran dan komitmen kolektif

Kepala sekolah berupaya untuk menyadari bahwa dirinya hidup, tumbuh, dan berkembang di lingkungan adat budaya Minangkabau dan senantiasa memiliki komitmen baik secara personal maupun kolektif untuk mempertahankan nilai-nilai yang menjadi acuan masyarakat Minangkabau dalam mengarungi kehidupan. Proses menumbuhkan kesadaran secara personal dilakukan dengan cara selalu menjaga wibawa dan menyadari posisinya sebagai pemimpin di lingkungan sekolah dan berupaya untuk mengarahkan warga sekolah (guru-guru dan peserta didik) untuk selalu menyadari pentingnya penanaman nilai-nilai edukatif lagu-lagu Minang, serta menjaga hubungan baik dengan orang tua atau masyarakat, sehingga dapat mewujudkan komitmen bersama untuk senantiasa menanamkan nilai-nilai yang sesuai dengan norma atau aturan adat Minangkabau.

b) Memberikan contoh sikap tauladan

Kepala sekolah sebagai pemimpin berupaya menjadi contoh dan tauladan bagi warga sekolah dan orang tua atau masyarakat dengan menjaga tindakan dan perilaku yang senantiasa menghargai dan menerapkan nilai-nilai edukatif lagu-lagu Minang sebagai kristalisasi dari norma/aturan adat Minangkabau, seperti menghargai, dan memperlakukan peserta didik sebagai manusia ciptaan Tuhan yang memiliki harga diri, bahkan di salah satu sekolah yang menjadi latar penelitian memperlakukan peserta didik laksana anak sendiri dan menggunakan slogan, "Kami mendidik dengan hati, peserta didik adalah anak-anak kami”.

Kesadaran dan komitmen kolektif terhadap penerapan nilai-nilai edukatif lagu-lagu Minang diikuti dengan proses sosialisasi baik dalam bentuk tindakan/aktivitas maupun dalam bentuk tertulis. 
1) Proses sosialisasi dalam bentuk tindakan/aktivitas.

Kepala sekolah melakukan beberapa kegiatan sebagai penunjang dalam penyaluran bakat dan minat peserta didik dalam bermain musik atau bernyanyi lagu-lagu Minang dalam kegiatan ekstrakurikuler, dengan demikian peserta didik juga memiliki kesempatan mengapresiasi dan mengekspresikan diri melalui lagu-lagu Minang. Dengan adanya kegiatan ekstrakurikuler memungkinkan peserta didik dan sivitas sekolah yang terlibat dalam kegiatan tersebut melakukan proses interaksi dan sosialisasi, serta selalu memperhatikan tindakan dan perilaku yang sesuai dengan nilai-nilai edukatif lagu-lagu Minang. Di samping itu, kepala sekolah juga memberikan kesempatan kepada peserta didik untuk mengikuti lomba memainkan musik atau lagu-lagu Minang, baik di tingkat lokal, provinsi, maupun nasional.

2) Proses Sosialisasi Secara Tertulis.

Proses sosialisasi dalam bentuk tertulis dilakukan dengan membuat regulasi-regulasi yang berkaitan dengan penanaman nilai-nilai dalam bentuk tertulis dan tidak tertulis. Regulasi tertulis diberikan dalam bentuk tempelan peraturan sekolah di papan pengumuman dan pemajangan banner yang memuat visi, misi, tujuan sekolah, dan poster-poster yang berisikan nilai-nilai budaya yang menjadi kekhasan masing-masing sekolah, misalnya budaya malu peserta didik yang memiliki prestasi, salah satunya adalah prestasi sebagai juara lomba bermain musik Minang maupun nyanyi Minang. Di samping itu, juga dilakukan pemajangan berbagai bentuk visualisasi adat Minangkabau, baik pemajangan rumah gadang, peralatan-peralatan yang digunakan oleh orang Minang, seperti carano (tempat sirih sebagai lambang penerimaan dan pemuliaan terhadap tamu), poster tokoh-tokoh nasional yang berasal dari Minangkabau, dan peribahasa atau pantun dalam bahasa Inggris, Bahasa Indonesia, dan Bahasa Minangkabau.

\section{Guru-guru}

Guru-guru khususnya yang memiliki latar belakang Minankabau selalu berupaya untuk menyadari bahwa dirinya hidup, tumbuh, dan berkembang di lingkungan adat budaya Minangkabau dan senantiasa memiliki komitmen baik secara personal maupun kolektif untuk mempertahankan nilai-nilai yang menjadi acuan masyarakat Minangkabau dalam mengarungi kehidupan. Upaya untuk menyadari dan berkomitmen dalam menerapkan nilai-nilai tersebut dilakukan dengan senantiasa 
menampilkan contoh sikap teladan, selalu menghargai dan menyayangi peserta didik laksana anak sendiri.

Proses internalisasi nilai-nilai edukatif lagu-lagu Minang lainnya yang dilakukan guru-guru, khususnya guru pendidikan seni musik terlihat dari proses pembelajaran. Guru pendidikan seni musik memberikan pembelajaran seni musik dengan memberikan kesempatan kepada peserta didik untuk mengapresiasi dan mengekspresikan dirinya dalam bermain musik Minang atau menyanyikan lagu-lagu Minang, serta berupaya menstimulus peserta didik untuk mengidentifikasi kandungan nilai-nilai yang terkandung dalam lagu-lagu Minang.

Proses pembelajaran seni musik tentang bermain musik Minang dan menyanyikan lagu-lagu Minang, baik secara solo, duet, trio, maupun penampilan musik Minang secara bersama-sama (ensambel) serta menyanyikan lagu-lagu Minang secara bersama-sama dalam bentuk vokal grup dan paduan suara memungkinkan terjadinya proses interaksi dan sosialisasi antara guru dengan peserta didik maupun antar sesama peserta didik. Proses interaksi dan sosialisasi tersebut mengacu pada nilai-nilai edukatif lagu-lagu Minang dengan mencerminkan tindakan dan perilaku yang saling menghargai, memiliki kepedulian, dan menjaga keharmonisan dengan sesama anggota dalam sebuah penampilan musik atau lagu-lagu Minang.

\section{Orang Tua/Masyarakat}

Orang tua/masyarakat memiliki peran yang sangat besar dalam proses internalisasi dan sosialisasi nilai-nilai edukatif lagu-lagu Minang di lingkungan rumah atau masyarakat. Pendidikan pertama kali dilakukan di rumah antara orang tua dengan anaknya. Pola didikan dan contoh sikap teladan yang dilakukan orang tua di lingkungan rumah sangat berpengaruh terhadap tindakan dan perilaku yang dicerminkan oleh peserta didik. Proses internalisasi yang dilakukan orang tua/masyarakat dilakukan dengan menumbuhkan kesadaran diri dan anak-anaknya untuk senantiasa menjaga dan menerapkan nilai-nilai adat Minangkabau.

Orang tua berupaya untuk memosisikan dirinya sebagai orang tua dan tauladan anak-anaknya, serta selalu bertindak dan berperilaku selayaknya sebagai orang tua Minangkabau yang selalu mengenalkan, mengarahkan, dan berupaya menerapkan norma atau adat Minangkabau terhadap anaknya, di samping menggunakan bahasa Minang ketika berinteraksi dan berkomunikasi dengan anakanak. Orang tua juga memberikan kesempatan kepada anak-anak untuk 
memperdengarkan lagu-lagu Minang, baik dalam bentuk Video Compact Disk (VCD) maupun audio CD.

\section{Proses Enkulturasi}

Proses enkulturasi yang dilakukan warga sekolah (kepala sekolah, guru-guru, tenaga administasi, dan orang tua/masyarakat) terhadap nilai-nilai edukatif lagu-lagu Minang dilakukan dengan cara membiasakan, menyesuaikan pikiran, tindakan dan perilaku yang dilakukan seperti yang telah dibahas pada proses internalisasi dan sosialisasi nilai-nilai edukatif lagu-lagu Minang.

Proses enkulturasi dapat juga dilakukan dengan menggunakan intervensi oleh semua pihak sesuai dengan aturan dan prosedur sekolah yang berlaku atau sesuai dengan cara orang tua memperlakukan anak-anak mereka sendiri, baik ketika peserta didik berada di dalam lingkungan sekolah, dan oleh orang tua/masyarakat ketika peserta didik berada di luar lingkungan sekolah atau ketika berada di rumah. Kepala sekolah, guruguru, dan orang tua pun dapat melakukan hal tersebut, jika norma atau aturan yang telah diberikan kepada peserta didik baik dalam bentuk tertulis maupun secara lisan tidak terlaksana dilakukan dengan baik.

\section{SIMPULAN}

Peran warga sekolah dalam pembudayaan nilai-nilai edukatif lagu-lagu Minang melalui gerakan literasi budaya di sekolah dasar yaitu: latar belakang, peran, dan intervensi budaya serta menjalin hubungan kerjasama yang baik antar warga sekolah, memberikan contoh sikap tauladan, sehingga melahirkan kesadaran kolektif untuk senantiasa mengimplementasikan nilai-nilai edukatif tersebut dalam kehidupan seharihari peserta didik secara kontiniu.

Proses pembudayaan nilai-nilai edukatif lagu-lagu Minang secara khusus lebih dititikberatkan pada kemampuan guru pendidikan seni musik untuk memberikan kesempatan kepada peserta didik untuk mengapresiasi, mengekspresikan, dan berliterasi budaya dalam mengimplementasikan nilai-nilai edukatif lagu-lagu Minang, baik ketika peserta didik berada di sekolah atau di masyarkat.

\section{REFERENSI}

Amir M.S. (2011). Adat Minangkabau: Pola hidup dan tujuan hidup orang Minang. Jakarta: Citra Harta Prima.

Astuti, K.S. (2010, Juni 11-13). Shaping morality through music learning in formal schools in Indonesia: An evaluation study. Artikel dipublikasikan pada Asia 
Pasific Network for Moral Education 5th dalam Annual Conference Interdisciplinary Moral Education in Asia's Globalising Societies; Concept and Practices. Japan: Nagasaki University.

Barendregt, Bart. (2002). The sound of 'longing for home': Redefining a sense of community through Minang popular music. Bijdragen tot de Taal-, Land- en Volkenkunde, 158, No: 3, 411-450: Leiden University.

Budiman, S. (2011, Maret 6). Lagu Minang Baru Muncul di Era 70-an. Padang: Harian Haluan Padang.

Darwis. (2005, November 28). Tafsir pantun Minang I. Artikel 655. Diambil pada tanggal 22 Januari 2012, dari http://www.cimbuak.net/content/view/655/5/1/1/.

Desyandri. (2015). Nilai-nilai Edukatif Lagu-lagu Minang untuk Membangun Karakter Peserta Didik. Diunduh dari http://journal.uny.ac.id/index.php/jppfa/article/view/7566. Jurnal Pembangunan Pendidikan; Fondasi dan Aplikasi, Vol.3, No. 2, halaman 126-141.

Desyandri. (2017). Interpretasi Nilai-nilai Edukatif Lagu Kambanglah Bungo untuk Membangun Karakter Peserta Didik (Suatu Kajian Hermeneutik). Komposisi: Jurnal Pendidikan Bahasa, Sastra, dan Seni, Vol.18, No.1 (March 2017).

Fraser, J. (2011). Pop song as custom: Weddings, ethnicity, and enterpreneurs in West Sumatra. Jurnal Ethnomusicology Sping/Summer, Vol. 55, No. 2, p. 200-228. Ohio: Society for Ethnomusicology.

Hajizar. (2012, Maret 13). Lagu Padang Dulu dan Kini. Artikel. Diambil pada tanggal 3 Maret 2014, dari http://albiouna.com/umum/lagu-padang-dulu-dan-kini.

Hakimy, I. (2004). Rangkaian mustika adat basandi syarak di Minangkabau. Bandung: Rosda Karya.

Hoffman, T. K. (1991). Cultural Literacy Is More Than Reading and Writing. A Review Essay.International Social Science Review, Vol. 66, No. 1 (WINTER 1991), pp. 33-36.

Kemendibud. (2016). Kajian dan Pedoman Penguatan Pendidikan Karakter (PPK). Kemendikbud: Jakarta.

Kemendikbud. (2016). Gerakan Literasi untuk Tumbuhkan Budaya Literasi. Media Komunikasi dan Informasi "Jendela" Pendidikan dan Kebudayaan. Jakarta: Kemendikbud.

Ki Hadjar Dewantara. (1977). Pendidikan: Bagian I. Yogyakarta: Majelis Luhur Persatuan Taman Siswa.

Ki Suratman. (1987). Pokok-pokok ketamansiswaan. Yogyakarta: Majelis Luhur Persatuan Taman Siswa.

Koentjaraningrat. (2011). Pengantar antropologiI. Jakarta: Rineka Cipta.

Naim, M. (2003). Konflik dan konsensus antara adat dan syara' di Minangkabau dalam reaktualisasi Adat Basandi Syara', Syara' Basandi Kitabullah. Padang: PPIM.

Riadi, S. (2014, Mei). Lulus UN, pelajar di Padang malah tawuran. Padang: Republika Online. Diambil pada tanggal 10 Juni 2014 dari http://http://www.republika.co.id/berita/nasional/nusantaranasional $/ 12 / 05 / 26 / \mathrm{m} 4 \mathrm{mtqg}$.

Sairin, S. (2002). Perubahan sosial masyarakat Indonesia: Perspektif antropologi. Yogyakarta: Pustaka Pelajar Offset.

Tilaar, H.A.R. (2010). Paradigma baru pendidikan nasional. Jakarta: Rineka Cipta.

Zainuddin, M. (2010). Pelestarian dan eksistensi dinamis adat Minangkabau. Yogyakarta: Ombak. 